Journal of Southeast Asian

\title{
Appendix J: Focus Group Summary of the Hmong Student Association
}

Yeng Yang

University of Texas, San Antonio, yeng.yang@utsa.edu

\section{Recommended Citation}

Yang, Yeng (2011) "Appendix J: Focus Group Summary of the Hmong Student Association," Journal of Southeast Asian American Education and Advancement. Vol. 6 : Iss. 1, Article 11.

DOI: $10.7771 / 2153-8999.1027$

Available at: https://docs.lib.purdue.edu/jsaaea/vol6/iss1/11

This document has been made available through Purdue e-Pubs, a service of the Purdue University Libraries. Please contact epubs@purdue.edu for additional information.

This is an Open Access journal. This means that it uses a funding model that does not charge readers or their institutions for access. Readers may freely read, download, copy, distribute, print, search, or link to the full texts of articles. This journal is covered under the CC BY-NC-ND license. 


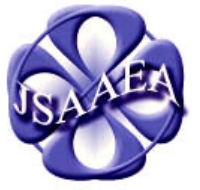

Volume 6 (2011)
Journal of Southeast Asian American

Education \& Advancement

WWW.JSAAEA.org
A peer-reviewed

scholarly journal published by the National Association for the Education \& Advancement of Cambodian, Laotian, and Vietnamese Americans (NAFEA)

\title{
Southeast Asian American Education 35 Years After Initial Resettlement: Research Report and Policy Recommendations
}

Conference Report of the National Association for the Education and Advancement of Cambodian, Laotian, and Vietnamese Americans

\author{
APPENDIX J \\ Focus Group Summary of the Hmong Student Association \\ Yeng Yang \\ San Francisco State University
}

\section{Southeast Asian Student Education (K-12): Access, Assessment, and Accountability}

Many participants felt that their high school teachers lacked the motivation in teaching. Many of their high school teachers did not follow school curriculums, were unorganized, and even resentful against some participants. Because of that, some participants did not try to establish close contact and/or relationship with their teachers and other school personnel. The participants agreed that having more inspiring teachers would benefit not just themselves, but all of the other students.

The participants reported that there were only a few Hmong teachers in their schools. At the administrator level, there were literally none. It is important to employ more Hmong teachers and administrators, as they can relate more to the students, and address their needs and issues accordingly. One recommendation they noted was that Hmong teachers should collaborate with one another and create specific programs that would target the needs and issues of Hmong students. Furthermore, because of the incompetence of the English language among many participants' parents, having the Hmong teachers to communicate with the parents would provide an opportunity for the parents to learn more about their children's educational performance.

\footnotetext{
(c) SOMAERIGHISRESERVED Readers are free to copy, display, and distribute this article, as long as the work is attributed to the author(s) and the Journal of Southeast Asian American Education \& Advancement, it is distributed for noncommercial purposes only, and no alteration or transformation is made in the work. More details of this Creative Commons license are available at http://creativecommons.org/licenses/by-nc-nd/3.0/. All other uses must be approved by the author(s) or JSAAEA.
} 
Many of the participants were considered as English language learners (ELL) or Limited English proficient (LEP) at one point in time during their high school or elementary years. Some participants perceived that one of their struggles was the inability to speak up in class. A few participants noted that though they speak English to each other, they did not feel it was sufficient enough to communicate with the teachers in a positive manner.

The opportunities to learn about Southeast Asian American history were very minimal as many did not recall. Some participants reported that the Vietnam War was mentioned briefly in their history class but not to the extent where it covered all the Southeast Asian groups delicately. Furthermore, all the participants agreed that school should include Southeast Asian history and culture in the core curriculum. As one student said, "We're like an endangered species."

Participants perceived that the California Exit Exam was within their knowledge as many passed the test. However, the participants believed that the end of year state test was not a good measurement of their academic comprehension. Some participants noted that they did not understand why they had to take the state test and felt that what they learned at school did not prepare them for these tests. All the students agreed that tests scores should not be the only important decision when measuring grade level promotion and high school graduation as other criteria should be factoring in as well.

\section{Southeast Asian Language and Culture Programs}

The participants expressed concerns about their language and culture in a melancholy sense because they feel that their language and culture are fading. Their language and culture is of great importance because they perceive that keeping the language and culture alive is similar as having a strong sense of identity.

Many participants noted that though they speak Hmong fluently, they could not read nor write in their language. Moreover, there were no Southeast Asian language programs offered at their schools. Because of that, they would like to have specific programs or activities that could bridge them between their language and culture.

One the most important issue that the participants agreed on was that if they speak only English to the current generation, their language may be lost within the next generation or so. As a result of that, there is a strong emphasis from the participants that speaking Hmong to the current generation is of great importance.

\section{Southeast Asian American Higher Education Access and Opportunities}

Note: No focus group discussion here, below is the author's experience

One of the obstacles that I encountered while attending college was that I did not know where to go get help when needed. My transition from high school to college was not smooth and I had to seek out and find my ways around, whether it be scheduling meetings with a guidance counselor, taking the appropriate courses, re-applying for financial aids, 
and so forth. To some students, this feeling of "lost and confusion" may be too overwhelmed, hence, they may drop out of college before ever reaching their full potentials. Providing Hmong American students with the adequate support and encouragement will certainly assist them to move forward in their college endeavor.

Having family support is one of the most significant contributions to my educational achievement. My parents supported me throughout my educational years. As a kid, my parents always made sure that I completed my homework before playing outside, watching television, etc. They also provided comfortable space and time that led me to focus to my full potentials. Though they could not help me academically, they provided the psychological and financial support. Sometimes, the encouragement given by the parents could make all the difference in a student's life.

One major reason why Hmong students dropped out of college is again, lack of role models, caring, and guidance from school personnel. When the students need help, there is no one to turn to who could understand them from their perspective. When they are confused and feel hopeless, there is no one to look up to, and guide them in the right direction. People without a sense of purpose in life and educational goals are the ones that are most likely to not succeed. Undoubtedly, there is a need to promote positive encouragement and thinking for not just Hmong students, but other Southeast Asian students as well, because I am positive that they too, can be triumphant like the rest.

\section{Southeast Asian American Communities}

The participants agreed that the public, their own neighbors, and students at their schools displayed a lack of comprehension about their culture. They recommended that schools should promote more culture diversity so that the Hmong culture, as well as other cultures, would be better acknowledged and appreciated.

The participants perceived that certain organizations in their community, created to support all Southeast Asians seem to be so far from reality. Some of the participants expressed their anger and asserted that the organizations should improve and reexamine their mission statements because Southeast Asian students, their parents, and lives are still struggling each and everyday.

The participants noted that compared to one generation ago, many Hmong students are attending higher education. They feel that more Hmong American women are attending college more than ever. Though this may be valid for these participants, it may not be valid elsewhere.

Participants feel that Hmong Americans in general, are still highly invisible within the host society. Furthermore, Hmong Americans are situated at the very bottom of America's social class. Because of that, the participants agreed that more research is essential to convey a better understanding and appreciation to the Hmong community, address their needs and issues, and social mobility in America. 


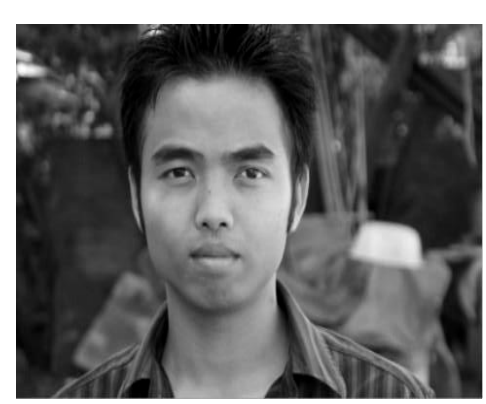

Yeng Yang is a M.A. candidate in the Department of Asian American Studies, College of Ethnic Studies at San Francisco State University (SFSU). His research interests include ethnic minority student educational attainments, socialization process between students and schooling, and Asian American contemporary issues. His current research focuses on Hmong American Women's educational achievement and social mobility. He currently serves as co-editor for the Asian American Studies Yellow Journal at SFSU. His work has recently been published in the Encyclopedia of Asian American Folklore and Folklife. 